\title{
Antihipertansif ílaç Kullanan Farklı Kuşak Hastaların Tedaviye Uyumunun İncelenmesi
}

\author{
Canan Demir Barutcu $\odot$
}

Mehmet Akif Ersoy Üniversitesi, Sağlık Bilimleri Fakültesi, İç Hastalıkları Hemşireliği Anabilim Dalı, Burdur, Türkiye

Canan Demir Barutcu, Dr. Öğr. Üyesi

İletişim:

Dr. Öğr. Üyesi Canan Demir Barutcu Mehmet Akif Ersoy Üniversitesi, Sağık Bilimleri Fakültesi, iç Hastalıkları Hemşireliği Anabilim Dalı, Burdur, Türkiye

Tel: +902482133515

E-Posta: canandemir2209@gmail.com
ÖZET

Amaç: Bu çalışma antihipertansif ilaç kullanan farkıı kuşak hastaların tedaviye uyumlarını incelemek amacıyla yapıımıştır.

Gereç ve Yöntemler: Tanımlayııı özellikte olan bu çalışma, Kasım 2017- Şubat 2018 tarihleri arasında, çalışmaya katılmayı kabul eden 132 hasta ile gerçekleştirilmiştir. Veriler, antihipertansif ilaç tedavisine uyum ölçeği kullanılarak yüz yüze görüşme yöntemi ile toplanmıştır. Verilerin analizinde kikare, tek yönlü varyans analizi, student t-testi kullanıımıştır.

Bulgular: Araştırmaya katılan Bebek Patlaması kuşağındaki hastaların toplam puan ortalaması $7.32 \pm 2.41$ iken, $X$ kuşağındaki hastaların toplam puan ortalaması $5.94 \pm 2.67$ olarak bulunmuştur. Bebek Patlaması Kuşağı ve X Kuşağı grubundaki hastalar arasında antihipertansif ilaç tedavisine uyum ölçeği toplam puan ortalaması açııından istatistiksel olarak anlamlı bir fark bulunmuştur $(\mathrm{p}<0.05)$. Bebek Patlaması kuşağındaki hastaların toplam puan ortalaması $X$ kuşağındaki hastalara göre daha yüksektir. Bebek Patlaması ve $X$ kuşağındaki hastaların bireysel özellikler ve klinik özellikleri ile antihipertansif ilaç tedavisine uyum ölçeği puan ortalamaları karşılaştırıldığında çalışma durumu, sosyal güvence ve gelir durumu açısından iki grup arasında anlamlı bir farklılık olduğu bulunmuştur $(p<0.05)$. Bunun yanı sıra diğer bireysel ve klinik özelliklerden cinsiyet, medeni durum, eğitim durumu, sigara kullanma, egzersiz yapma, ek bir kronik hastalığa sahip olma durumu arasında iki grup arasında anlamlı bir farklılık olmadığı bulunmuştur $(p>0.05)$.

Sonuç: Araştırmada X kuşağında olan antihipertansif ilaç kullanan hastaların tedaviye uyumlarının daha iyi olduğu bulunmuştur. Bu nedenle hemşirelerin ve sağık ekibinin diğer üyelerinin kuşaklar arası farklılıkları bilmesi, kuşakların özeliklerine göre yönlendirme yapması ve davranış değişiklikleri önermesi önemlidir.

Anahtar Kelimeler: Hipertansiyon, kuşaklar, tedavi uyumu, kronik hastalık

INVESTIGATION OF TREATMENT ADHERENCE OF DIFFERENT GENERATIONAL PATIENTS USING ANTIHYPERTENSIVE MEDICATION

\section{ABSTRACT}

Objectives: This study was conducted in order to investigate treatment adherence of different generational patients using antihypertensive medication.

Methods: This descriptive type of study was conducted from 132 patients. Data were collected by face-to-face interview method using the medication adherence scale. In the analysis of the data, : chi-square, one-way ANOVAand student t-test were used.

Results: The average adherence scale score of Baby Boomer who participated in the study was $7.32 \pm 2.41$ and Generation X patients who participated in the study was $5.94 \pm 2$.67. There was a statistically significant difference found among patients in Baby Boomers and Generation $X$ groups in terms of total average medication adherence scale score $(p<0.05)$. The total average score of Baby Boomer patients was higher than that of generation $X$ patients. When the individual characteristics and clinical characteristics of the two groups' patients were compared to the average scores of medication adherence scale, a significant difference was found between the two groups in terms of employment status, social security and income status. In addition, it was determined that there was no significant difference between the two groups in terms of other individual and clinical characteristics, including gender, marital status, educational status, smoking, exercising and status of having an accompanying chronic disease.

Conclusion: In this study, generation X patients who received antihypertensive medication were found to have a better treatment adherence. For this reason, it is important for nurses and other members of the healthcare team to know the intergenerational differences, to guide based on the characteristics of generations and to recommend behavioral changes.

Key words: Generations, hypertension, chronic disease, medication compliance (or Adherence?)
Gönderilme Tarihi : 13 Mart 2018

Revizyon Tarihi : 29 Temmuz 2018

Kabul Tarihi : 31 Temmuz 2018 
$\mathbf{M}$ odern dünyada teknolojik gelişmeler ve bilimsel ilerlemeler insanların yaşam biçimlerini, kültürlerini, sosyal çevrelerini ve iletişimlerin etkilemektedir. Bu gelişmeler ve değişikliklerin etkisi ile oluşan zaman dilimlerine jenerasyon, nesil ya da kuşak denilmektedir. Kuşak kavramı, aynı zaman diliminde doğmuş ve benzer deneyimler yaşamış insan topluluklarını tanımlamak için kullanılmaktadır. Her kuşak, kendine has özelliklere sahip olmakta ve böylece diğer kuşaklardan farklılaşmaktadır (1). Her kuşağın bulunduğu dönemin koşullarına göre farklı imkânlara sahip olması, bu bireylerin farklı şekillerde yetişmesine neden olmaktadır. Tüm bunların doğal bir sonucu olarak kuşaklar arasında algı, görüş, değer, tutum, davranış, yaşayış ve iletişim gibi konularda farklılıklar görülmektedir (2). Bu gibi farklılıkların hastaların hastalık süreçlerini yönetmede, tedaviye uyum sağlamada farklılık yaratabileceği düşünülmektedir. Tüm toplumlarda sık görülen kronik hastalıkların yönetilebilmesi, çeşitli davranış değişikliklerini beraberinde getirmektedir. Bu hastalıklardan biri de yüksek morbidite ve mortalite oranlarına sahip, prevelansı her geçen yıl artan önemli bir sağlık problemi olan hipertansiyondur. Hipertansiyon, tedavi edilmediği takdirde miyokart enfarktüsü, kalp yetersizliği, inme, böbrek yetersizliği ve ölüme neden olan önemli bir halk sağlığı sorunudur $(3,4)$. Türk Hipertansiyon Prevalans (PatenT2) çalışmasına göre Türkiye'de hipertansiyon prevalansının \%30.3 olduğu bildirilmiştir (5). Hipertansiyon tanısı ile birlikte yaşam boyu süren bir tedavi süreci başlamaktadır. Kan basıncının kontrolü tıbbi tedavi, diyet, tuz, sigara, alkol kısıtlaması ve egzersiz ile sağlanmaktadır. Hipertansiyon tedavisinde temel amaç kan basıncını normal sınırlarda tutmak ve komplikasyonları önlemektir. Tedavinin etkinliğinde rol oynayan en önemli faktör hastanın tedaviye uyumudur. Uyum, hastanın ilaçlarını kullanması, diyetini uygulaması ve diğer yaşam biçimi değişikliklerini yerine getirmesi anlamına gelmektedir (4). Uyumsuzluk ise, ilaç tedavisine bağlı kalmamak, reçetesini yazdırmamak, diyete uymamak gibi özellikleri içermektedir. Uyumsuzlukla ilgili hastalar ilaç almanın yararına inanmazlar, yeterli dozda almayı unuturlar, ya da bilinçli olarak ilaçlarını almazlar (6). İlaç tedavisine uyumsuzluk, hem normal kan basıncının sürdürülememesi hem de hipertansiyonla ilişkili komplikasyon insidansının artmasında etkili ve önemli bir faktördür. Genç nüfusa göre yaşlıların daha uzun süreli ve daha fazla ilaç kullanımı, yaşlı bireylerde tedaviye uyum sorununun sık görülmesine neden olmaktadır (4). Bu noktada farklı kuşaklara mensup bireylerin hastalığa uyum konusundaki davranışlarının farklı olabileceği düşünülmüş ve bu nedenle çalışma antihipertansif ilaç kullanan farklı kuşak hastaların tedaviye uyumları arasında farklıılılarını belirlemek amacıyla tanımlayıcı olarak yapılmıştır.

\section{Araştırma Sorusu}

- Antihipertansif ilaç kullanan farklı kuşak hastaların tedaviye uyumları arasında fark var mıdır?

\section{Gereç ve Yöntem}

Tanımlayıcı tipte olan bu araştırmanın örneklemini Kasım 2017- Şubat 2018 tarihleri arasında, bir devlet hastanesine poliklinik hizmeti almaya gelen, antihipertansif ilaç kullanan, araştırmaya katılmayı gönüllü olarak kabul eden toplam 132 hasta oluşturmuştur.

\section{Veri Toplama Araçları}

\section{Hasta Tanılama Formu}

Hastaların doğum tarihi, cinsiyeti, eğitim durumu, medeni durumu, çalışma durumu, gelir durumu, sigara kullanma durumu, egzersiz yapma durumu, hastalık süresi ve ek bir kronik hastalığa sahip olma durumu gibi özelliklerini içeren toplam 11 sorudan oluşmaktadır.

\section{Antihipertansif Ilaç Tedavisine Uyum Ölçeği}

Hastaların ilaç tedavisine uyumunu değerlendirmek için 2003'te Morisky ve arkadașları tarafından geliștirilen ve Demirezen tarafından (2006) Türk toplumuna uyarlanan antihipertansif ilaç tedavisine uyum ölçeği kullanılmıştır (7). Ölçek toplam dokuz maddeden oluşmaktadır. Ölçeğin ilk 8 sorusunda cevaplar "Evet" ve "Hayır" olarak yanıtlanmakta, "Evet" 1, "Hayır" 0 olarak kodlanmaktadır. Dokuzuncu soruda her bir madde için 1. "hiç/nadiren", 2."ara-sıra", 3."bazen", 4.."genellikle”, 5. "her zaman" seçeneklerinden birisinin işaretlenmesi gerekmektedir. Ölçekten alınan toplam puan 1-13 puan arasında değişmektedir. Antihipertansif ilaç tedavisine uyumlu ve uyumsuz tanımlamaları, toplam ölçek puanına göre 1-7 puan alanlar tedaviye uyumlu, 8 ve üzerinde puan alanlar uyumsuz olarak tanımlanmaktadır. Demirezen (2006) tarafından yapılan çalışmada ölçeğin Cronbach a değeri 0.82 olarak bulunmuştur. Bu çalışmada ölçeğin Cronbach alpha katsayısı 0.70 olarak bulunmuştur.

\section{Verilerin Toplanması ve Analizi}

Araştırmanın yapılabilmesi için Mehmet Akif Ersoy Üniversitesi Girişimsel Olmayan Araştırmalar Etik Kurul'undan etik kurul izni (GO 2017/138) alınmıştır. Hastalar araştırma hakkında bilgilendirilmiş ve onamları alınmıştır. Veriler, yüz-yüze görüşme yolu ile toplanmıştır. Veriler, SPSS 22.0 programı kullanılarak sayı, yüzde 
dağılımları, student t-testi, ki kare analizi ve tek yönlü varyans analizi ile değerlendirilmiştir ve istatistiksel anlamlılık düzeyi $p<0.05$ olarak kabul edilmiştir.

\section{Bulgular}

Araştırma kapsamına alınan hastaların \%44.7'sinin Bebek Patlaması kuşağında, \%55.3'nün X kuşağında olduğu bulunmuştur. Araştırmaya katılan hastaların \%68.2'si kadın, \%73.5'i ilköğretim mezunu, \%80.3'ü evli ve \%65.2'si emekli veya çalışmamaktadır. Katılımcıların \%84.8'inin sosyal güvencesi olduğu, \%57.6'sının gelir durumunun gider durumuna eşit olduğu, \%81.1'inin sigara kullanmadığı, \%66.7'sinin egzersiz yapmadığı ve \%51.5'inin hipertansiyona ek bir kronik hastalığı olduğu bulunmuştur. Katılımcıların ortalama hastalık süresi $11.63 \pm 7.41$ yıl olarak bulunmuştur. Araştırmaya katılan Bebek Patlaması kuşağındaki hastaların toplam puan ortalaması $7.32 \pm 2.41$ iken, $\mathrm{X}$ kuşağındaki hastaların toplam puan ortalaması $5.94 \pm 2.67$ olarak bulunmuştur.

Araştırma kapsamına alınan Bebek Patlaması Kuşağı ve $X$ Kuşağı grubundaki hastalar arasında cinsiyet, medeni durum, eğitim durumu, sosyal güvence, gelir durumu, sigara kullanma, egzersiz yapma ve ek bir kronik hastalığa sahip olma durumu açısından istatistiksel olarak anlamlı bir fark bulunmamaktadır ( $p>0.05$ ). Bebek Patlaması Kuşağı ve $X$ Kuşağı grubundaki hastalar arasında sadece çalışma durumu ve hastalık süresi açısından istatistiksel olarak anlamlı bir fark bulunmaktadır $(p<0.05)$.

Bebek Patlaması Kuşağı ve $X$ Kuşağı grubundaki hastalar arasında antihipertansif ilaç tedavisine uyum ölçeği toplam puan ortalaması açısından istatistiksel olarak anlamlı bir fark bulunmaktadır ( $p<0.05$ ). Bebek Patlaması kuşağındaki hastaların toplam puan ortalaması X kuşağındaki hastalara göre daha yüksek bulunmuştur (Tablo 1).

Bebek Patlaması ve $X$ kuşağındaki hastaların bireysel özellikler ve klinik özellikleri ile antihipertansif ilaç tedavisine uyum ölçeği puan ortalamaları karşılaştıııldığında çalışma durumu, sosyal güvence $(U=785.000, p=.032)$ ve gelir durumu (KW=11.191, $\mathrm{p}=.004)$ açısından iki grup arasında anlamlı bir farklılık olduğu bulunmuştur $(p<0.05)$ (Tablo 2). Bunun yanı sıra diğer bireysel ve klinik özelliklerden cinsiyet, medeni durum, eğitim durumu, sigara kullanma, egzersiz yapma ek bir kronik hastalığa sahip olma durumu arasında iki grup arasında anlamlı bir farklılık olmadığı bulunmuştur ( $p>0.05$ ) (Tablo 2).

Tablo 1. Hastaların tanıtıcı özelliklerinin kuşaklara göre karşılaştırımas

\begin{tabular}{|c|c|c|c|}
\hline $\begin{array}{l}\text { Hastalara Ait } \\
\text { Özellikler }\end{array}$ & $\begin{array}{c}\text { Bebek Patlaması } \\
\text { Kuşağı } \\
(1946-1964)(n=59)\end{array}$ & $\begin{array}{c}\text { X Kuşağı } \\
(1965-1979) \\
(n=73)\end{array}$ & $\begin{array}{c}\text { Istatistikse } \\
\text { Analiz }\end{array}$ \\
\hline & Sayı \% & Sayı \% & \\
\hline \multicolumn{4}{|l|}{ Cinsiyet } \\
\hline Kadın & $39(29.5)$ & $51(38.6)$ & $\chi 2=.785$ \\
\hline Erkek & $20(15.2)$ & $22(16.7)$ & $p=.709 *$ \\
\hline \multicolumn{4}{|l|}{ Medeni durum } \\
\hline Evli & $49(37.1)$ & $57(43.2)$ & $\chi^{2}=.622$ \\
\hline Bekar & $10(7.6)$ & $16(12.1)$ & $\mathrm{p}=.516^{\star}$ \\
\hline
\end{tabular}

\section{Eğitim durumu} Illköğretim Ortaöğretim/Lise Üniversite ve üzeri

Çalışma durumu

Çalışan

\section{Sosyal güvence}

Var
Yok

Gelir Durumu

Gelir giderden fazla

Gelir gidere eşit

Gelir giderden az

\section{Sigara kullanma}

$\begin{array}{lccc}\text { Evet } & 13(9.8) & 12(9.1) & \chi 2=.554 \\ \text { Hayır } & 46(34.8) & 61(46.2) & \mathrm{p}=.504^{*}\end{array}$

\section{Egzersiz yapma}

Evet $\quad 18(13.6) \quad 26(19.7) \quad \chi 2=.665$

Hayı

$41(31.1)$

$47(35.6) \quad p=.581$

\begin{tabular}{|c|c|c|c|}
\hline \multicolumn{4}{|l|}{ Ek kronik hastalık } \\
\hline Evet & $35(26.5)$ & $33(25.0)$ & $\chi 2=.150$ \\
\hline Hayır & 24(18.2) & $40(30.3)$ & $p=.118^{*}$ \\
\hline & $\bar{x} \pm S S$ & $\bar{x} \pm S S$ & \\
\hline $\begin{array}{l}\text { Hastalık } \\
\text { Süresi (YıI) }\end{array}$ & $13.40 \pm 6.59$ & $10.20 \pm 7.76$ & $\begin{array}{l}t=2.517 \\
p=.013\end{array}$ \\
\hline $\begin{array}{l}\text { Antihipertansif } \\
\text { İlaç Tedavisine } \\
\text { Uyum Ölceği }\end{array}$ & $7.32 \pm 2.41$ & $5.94 \pm 2.67$ & $\begin{array}{l}t=3.074 \\
p=.003\end{array}$ \\
\hline
\end{tabular}

*n sayısı 25'in altında olduğu için Yates Düzeltmesi yapıımıştır.

**Beklenen sayı 5 'in altında olduğu için Fisher Düzeltmeli $\chi^{2}$ kullanılmış̧ır. 
Tablo 2. Anthipertansif ilaç tedavisine uyum ölçeği puan ortalamalarının bireysel özellikler ve klinik özelliklere göre karşılaştırıması

\begin{tabular}{|c|c|c|c|}
\hline \multirow[t]{2}{*}{$\begin{array}{l}\text { Hastalara Ait } \\
\text { Özellikler }\end{array}$} & \multicolumn{3}{|c|}{$\begin{array}{c}\text { Antihipertansif İlaç } \\
\text { Tedavisine Uyum Ölçeği istatistiksel Analiz }\end{array}$} \\
\hline & $n$ & $\bar{x} \pm S S$ & \\
\hline \multicolumn{4}{|l|}{ Cinsiyet } \\
\hline Kadın & 90 & $6.57 \pm 2.56$ & $t=.109$ \\
\hline Erkek & 42 & $6.52 \pm 2.83$ & $p=.913$ \\
\hline \multicolumn{4}{|l|}{ Medeni durum } \\
\hline & 106 & $6.46 \pm 2.63$ & $U=1242.000$ \\
\hline Bekar & 26 & $6.96 \pm 2.66$ & $p=.433$ \\
\hline \multicolumn{4}{|l|}{ Eğitim durumu } \\
\hline İlköğretim & & $6.74 \pm 2.61$ & \\
\hline Ortaöğretim/Lise & 2114 & $6.33 \pm 2.41$ & $\begin{array}{c}n v v=2.010 \\
p=314\end{array}$ \\
\hline Üniversite ve üzeri & & $5.64 \pm 3.07$ & \\
\hline \multicolumn{4}{|l|}{ Çalışma durumu } \\
\hline Çalışan & 46 & $5.60 \pm 2.58$ & $t=-3.131$ \\
\hline Çalışmayan & 86 & $7.06 \pm 2.53$ & $p=.002^{\star}$ \\
\hline \multicolumn{4}{|l|}{ Sosyal güvence } \\
\hline Var & 112 & $6.36 \pm 2.64$ & $U=785.000$ \\
\hline Yok & 20 & $7.65 \pm 2.41$ & $p=.032^{\star}$ \\
\hline \multicolumn{4}{|l|}{ Gelir Durumu } \\
\hline Gelir giderden fazla & 27 & $5.11 \pm 2.63$ & \\
\hline Gelir gidere eşit & 76 & $6.96 \pm 2.65$ & $\begin{array}{l}n=004^{*} \\
n v=11 . \mid 11\end{array}$ \\
\hline Gelir giderden az & 29 & $6.79 \pm 2.16$ & \\
\hline \multicolumn{4}{|l|}{ Sigara kullanma } \\
\hline Evet & 25 & $6.80 \pm 2.53$ & $U=1250.500$ \\
\hline Hayır & 107 & $6.50 \pm 2.67$ & $p=.611$ \\
\hline \multicolumn{4}{|l|}{ Egzersiz yapma } \\
\hline Evet & 44 & $5.95 \pm 2.80$ & $t=-1.884$ \\
\hline Hayır & 88 & $6.86 \pm 2.51$ & $p=.062$ \\
\hline \multicolumn{4}{|l|}{ Ek kronik hastalık } \\
\hline Evet & 68 & $6.32 \pm 2.55$ & $t=-1.064$ \\
\hline Hayır & 64 & $6.81 \pm 2.72$ & $p=.289$ \\
\hline
\end{tabular}

\section{Tartışma}

Íkinci Dünya Savaşı'ndan hemen sonraki "nüfus patlaması" yıllarında doğan bu bir milyar bebeğe "Bebek Patlaması (Baby Boomers)" denmektedir (8). Sadakat duyguları yüksek, kanaatkârdırlar, aynı yerde uzun süre çalışmayı tercih ederler (9). Bebek Patlaması kuşağının temel değerleri arasında, iyimserlik, takım ruhu, kişisel tatmin, sağlık ve zindelik, kişisel gelişim, iş ve katılım yer almaktadır (10, 11). 1965-1979 yılları arasında doğan X kuşağı, daha çok risk alma ve gelenekler gibi otoriteleri önceki kuşaklara göre daha çok sorgulama eğiliminde olmalarının yanında aile odaklı, kendine güvenen, açık fikirli olma gibi özelliklere sahiptir $(10,11)$. X Kuşağı değişimi olumlu karşılayan, güçlü teknik becerilere sahip ve sonuç odaklı bir kuşak olarak tanımlanmaktadır $(11,12)$. Sonuç olarak her kuşağın içinde bulunduğu dönemin koşullarına göre farklı imkânlara sahip olması, bu bireylerin farklı şekillerde yetişmesine neden olmaktadır. Tüm bunların doğal bir sonucu olarak ise kuşaklar arasında algı, görüş, değer, tutum, davranış, yaşayış ve iletişim gibi konularda farklılıklar görülmektedir (2). Bu gibi farklılıkların hastaların hastalık süreçlerini yönetmede, tedaviye uyum sağlamada farklılık yaratabileceği düşünülmektedir. Bu nedenle bu çalışma kuşaklar arası uyum davranışlarının farklı olabileceği düşüncesiyle farklı kuşağa mensup hastaların tedaviye uyum konusunda yaşadıkları farklııkları saptamak amacıyla yapılmıştır.

Bebek Patlaması Kuşağı ve X Kuşağı grubundaki hastalar arasında antihipertansif ilaç tedavisine uyum ölçeği toplam puan ortalaması açısından istatistiksel olarak anlamlı bir fark bulunmaktadır ( $p$ 0.05). Bebek Patlaması kuşağındaki hastaların toplam puan ortalaması $(7.32 \pm 2.41)$, $X$ kuşağındaki hastalara (5.94 \pm 2.67$)$ göre daha yüksek bulunmuştur. Antihipertansif ilaç tedavisine uyum ölçeğ toplam puanına göre 1-7 puan alanlar tedaviye uyumlu, 8 ve üzerinde puan alanlar uyumsuz olarak tanımlanmaktadır. Bu anlamda yaş arttıkça ve kuşak değiştikçe hastaların antihipertansif ilaç tedavisine uyumları azalmaktadır.

Bebek Patlaması ve X kuşağındaki hastaların bireysel özellikler ve klinik özellikleri ile antihipertansif ilaç tedavisine uyum ölçeği puan ortalamaları karşılaştırıldığında çalışma durumu, sosyal güvence ve gelir durumu açısından iki grup arasında anlamlı bir farklılık olduğu bulunmuştur ( $p$ $<0.05$ ). Bunun yanı sıra diğer bireysel ve klinik özelliklerden cinsiyet, medeni durum, eğitim durumu, sigara kullanma, egzersiz yapma ek bir kronik hastalığa sahip olma durumu arasında iki grup arasında anlamlı bir farklııı olmadığı bulunmuştur $(p>0.05)$.

Gün ve Korkmaz (2012) hipertansiyon tanısı konmuş hastaların yaşam kalitesi, tedavi uyumları ve etkileyen faktörleri incelemek amacıyla yaptıkları çalışmada hastaların sadece \%15.8'inin tedaviye tam uyumlu olduğu, tedaviye uyumda yaş, cinsiyet, eğitim durumu, medeni durumun yanı sıra yaşam kalitesinin de etkili olduğu belirlenmiştir (13). Çalışmamızda hastaların uyum ölçeğinden aldıkları puan ortalaması ise $6.56 \pm 2.63$ olarak bulunmuştur. Buda hastaların tedaviye uyumlu olduklarını göstermektedir. Ancak çalışmadan farklı olarak çalışmamızda tedaviye uyumda cinsiyet, medeni durum ve eğitim durumu arasında fark bulunmamaktadır. Ayrıca çalışmaya oranla çalışmamızdaki örneklem grubunun tedaviye daha uyumlu olduğu söylenebilir. Bunun nedeni olarak araştırmada farklı uyum ölçeklerinin kullanılması ve hastaların farklı sosyodemografik özelliklere sahip olması olabilir. 
Özdemir ve arkadaşlarının (2016) geriatrik hipertansif hastaların ilaç tedavisine uyumlarını değerlendirmek amacıyla yaptıkları çalışmada hastaların ortalama yaşı $74.7 \pm 6.0$ olarak bulunmuştur. Hastaların \%93.4'ü hipertansiyonun yanısıra diğer sağlık sorunları da yaşamaktadır. Geriatrik hipertansif hastaların ilaca uyum öz-etkililik puanlarının (45.05 \pm 6.06$)$ yüksek olduğu belirlenmiştir. Sonuç olarak hipertansif yaşlı bireylerin ilaç tedavilerine uyumlu oldukları saptanmıştır (4). Çalışmamızda sadece geriatrik hastalar değerlendirilmediği için yaş ortalaması daha yüksektir, bunun yanı sıra çalışmamızda hastaların \%51.5'inin hipertansiyona ek bir kronik hastalığı olduğu bulunmuştur. Bunun nedeni yaş arttıkça kronik hastalıkların görülme sıkığının artmasıdır. Illaca uyum puan ortalaması ve hastaların uyumlu çıkması Özdemir ve arkadaşlarının (2016) çaIışma sonucuyla paraleldir. Çalışmamızda antihipertansif ilaç kullanan hastaların tedaviye uyum gösterdikleri, yaş arttıkça yani kuşak değiştikçe uyumun azaldığı ve iki kuşak arasındaki farkın anlamlı olduğu bulunmuştur. Bunun nedeninin yaş artışının hastaların uyum düzeyi konusunda dezavantaj yaratması olabileceği düşünülmüştür.

Irmak ve arkadaşlarının (2007) bir eğitim programının hipertansiyon tanısı konan hastaların yaşam biçimi değişikliği ve ilaç tedavisi uyumuna etkisini belirlemek amacıyla yaptığı çalışmada hastaların yaş ortalaması $51.0 \pm 9.9$ yıl, \%64. 4'ü kadın ,\%53.3'ü ilköğretim mezunu, \%84.4'ü evli ve hastaların hipertansiyon tanısı alma suresi $4.39 \pm 4.96$ yıl olarak bulunmuştur. Çalışmada, ilaç tedavisine uyumun çok iyi olduğu saptanmıştır (3). Çalışmamızda hastaların kronik hastalık tanı süresinin $(11.63 \pm 7.41)$ daha uzun olduğu bulunmuştur. Bunun nedeni örneklem seçiminde 1946-1979 gibi tarih aralıklarının seçilmesi ve örneklem sayısının daha fazla olması olabilir. Çalışmamızda hastaların \%68.2'sinin kadın olduğu ve \%73.5'sinin ilköğretim mezunu olduğu bulunmuştur. Çalışmamıza katılan toplam hasta popülasyonu ile karşılaştııırsak çalışmaya paralel olarak hastaların tedaviye uyumlu olduğu bulunmuştur.

Tümer ve arkadaşlarının (2016) hipertansiyon hastalarının ilaç tedavisine uyum düzeyleri ve uyumu etkileyebilecek bireysel faktörleri incelemek amacıyla yaptıkları çalışmada katııımcıların yaş ortalamasının 59.45 $\pm 11.50, \% 54.4^{\prime}$ ünün kadın, \%81.2'sinin evli, \%54.7'sinin ilkokul mezunu ve \%25.5'inin sigara içtiği bulunmuştur. Hipertansiyon tanı süresi ortalaması $8.49 \pm 6.12$ yıl olup, $\% 48.1$ 'inin hipertansiyon dışında kronik bir hastalığının olduğu bulunmuştur. İlaç tedavisine uyumun yüksek olduğu, sigara içmeyen katılımcıların ölçek puan ortalaması sigara içenlere göre yüksek, fark ise istatistiksel olarak anlamlı bulunmuştur (14). Çalışmamıza paralel olarak hastaların \%80.3'ünün evli, \%73.5'inin ilköğretim mezunu, \%18.9'unun sigara kullandığı ve \%51.5'inin hipertansiyon dışında ek bir kronik hastalığı olduğu bulunmuştur. Ayrıca çalışmamızda da hastaların tedaviye uyumlu olduğu kuşağa göre değerlendirildiğinde ise yaşın artmasıyla uyumun azaldığı, başka bir deyişle Bebek Patlaması kuşağındaki hastaların X kuşağındaki hastalara oranla daha uyumsuz olduğu ve aradaki farkın istatistiksel olarak anlamlı olduğu bulunmuştur. Bunun nedeninin yaş ilerledikçe bilişsel fonksiyon kayıplarının artması, ek kronik hastalıkların ve komplikasyonlarının artması olabileceği düşünülmüştür. Çalışmaya paralel olarak sigara içenlerin uyum düzeylerinin içmeyenlere oranla daha düşük olduğu ancak farkın istatistiksel olarak anlamlı olmadığı bulunmuştur.

Atan ve Karabulutlu'nun (2015) hipertansiyon hastalarında yaşam biçiminin yaşam kalitesine ve tedavi uyumuna etkisini belirlemek amacıyla yaptıkları çalışmada hastaların; \%90'ının sigara kullandığı ve \%19.1'inin de fiziksel aktivite yaptığı bulunmuştur. Hastaların tedaviye uyumlarının yüksek olduğu belirlenmiştir (15). Çalışmamızda yaşam biçimi davranışları değerlendirilmediği için bu açıdan karşılaştırma yapılamamıştır. Ancak çalışmamıza katılan hastaların \%81.1'inin sigara kullanmaması açısından farklılık göstermektedir bunun yanı sıra çalışmamıza katılan hastaların \%33.3'ünün egzersiz yapıyor olması da çalışma sonucuyla paralellik göstermektedir.

Mert ve arkadaşlarının (2011) hipertansiyon hastalarının tedaviye uyumunun, sosyodemografik ve bazı hastalık özellikleri ile ilişkisini inceledikleri çalışmada hastaların yaş ortalaması $58.76 \pm 14.90$ olarak bulunmuştur (16). Çalışmaya katılan hastaların \%62.6'sının kadın olduğu ve hastaların antihipertansif ilaç tedavisine uyum ölçek puanı ortalamasının da $4.66 \pm 2.23$ olduğu bulunmuştur. Sonuç olarak hastaların \%86.8'inin ilaç tedavisine uyduğu ve uyum puanı ile yaş, cinsiyet, eğitim düzeyi, medeni durum, çalışma durumu, gelir düzeyi, sigara alışkanlığı, alkol kullanımı, egzersiz yapma, hipertansiyon süresi ve eşlik eden kronik hastalıklar arasında anlamlı bir ilişki olmadığı saptanmıştır. Çalışmamızda hastaların antihipertansif uyum ölçeğinden aldıkları puanın daha yüksek (6.56 \pm 2.63) olduğu bulunmuştur. Bunun nedeninin örneklem yaş ortalamasının çalışmamızda daha yüksek olması ve hastaların yaşı artıkça uyum düzeylerinin azalması olabilir.

Aşılar ve Gözüm'ün (2017) hipertansiyon hastalarının tamamlayıcı sağlık yaklaşımı kullanımları ve bunun antihipertansif ilaç tedavisi uyumuna etkisini belirlemek amaCı ile yaptıkları çalışmada tamamlayıcı sağlık yaklaşımı 
kullanımının 65 yaş altındakilerde ve kadınlarda daha fazla olduğu ( $p<0.05)$, tamamlayıc sağlık yaklaşımı kullanımının kan basıncı kontrolü ve ilaç tedavisine uyumu üzerinde önemli bir etkisinin olmadığı bulunmuştur ( $p$ > 0.05). Hastaların ilaç uyumunun iyi düzeyde olduğu saptanmıştır (17). Çalışmamızda hastaların tamamlayıcı sağlık davranışları değerlendirilmediği için bu parametrelerle karşılaştırılması yapılmamıştır ancak çalışmadaki hasta popülasyonun ilaca uyumunun iyi düzeyde olması çalışma sonucumuzla paralellik göstermektedir.

Literatürde yer alan çalışmalarda kuşak farklılıkları ile tedaviye uyum çalışmalarına ulaşılamadığı için antihipertansif ilaç kullanan hastaların uyum düzeylerini inceleyen çalışmaların yaş ve diğer sosyo-demografik verileri ile karşılaştırma yapılabilmiştir.

\section{Sonuç ve öneriler}

Bilimsel ve teknolojik gelişmelerin etkisi ile oluşan kuşak özelliklerinin bilinmesi kuşakları anlamak için önemlidir. Her kuşak, kendine has özelliklere sahip olduğu için kuşak farklııkları oluşmaktadır (Köse, 2014). Profesyonel sağlık ekibinin önemli üyelerinden olan hemşirelerin kuşakları

\section{Kaynaklar}

1. Köse S, Oral L, Tetik HT. Y Kuşağının Birinci ve İkinci Yarısında İş Değerlerinin Karşılaştııılması Üzerine Bir Araştırma. HUMANITAS 2014; 3: 149-69.

2. Tüybek C. Kuşaklararası Farlılık Açısından Üniversite Gençliği ve Aile. Selçuk Üniversitesi Sosyal Bilimler Enstitüsü, Yüksek Lisans Tezi, 2004.

3. Irmak Z, Türkcan Düzöz G, Bozyer İ. Bir Eğitim Programının Hipertansiyonlu Hastaların Yaşam Tarzı Ve İlaç Tedavisi Uyumuna Etkisi. Hemşirelik Yüksekokulu Dergisi 2007; 39-47.

4. Özdemir Ö, Akyüz A, Doruk H. Geriatrik Hipertansif Hastaların İlaç Tedavisine Uyumları. Bakırköy Tıp Dergisi 2016;12:195-201.

5. Türk Hipertansiyon ve Böbrek Hastalıkları Derneği. Türk Hipertansiyon Prevalans Çalışması PatenT2. 2012. http://www. turkhipertansiyon.org/prevelans_calismasi_2.php.(Erişim tarihi: 15.02.2018).

6. Hacıhasanoğlu R. Hipertansiyonda Tedaviye Uyumu Etkileyen Faktörler. TAF Prev Med Bull 2009;8:167-72.

7. Demirezen E. Türkiye'den ve Almanya'da Yaşayan Antihipertansif İlaç Kullanan Türklerde İlaç Tedavisine Uyum. İstanbul Üniversitesi Sağlık Bilimleri Enstitüsü, Doktora Tezi, 2006.

8. Keleş HN. Y Kuşağı Çalışanlarının Motivasyon Profillerinin Belirlenmesine Yönelik Bir Araştırma. Bahçeşehir Üniversitesi Organizasyon ve Yönetim Bilimleri Dergisi 2011; 3: 129-39. arası farklılıkları anlaması, hastaların uyum davranışlarını saptaması açısından oldukça önemlidir. Çalışma sonucuna göre Bebek Patlaması ve $X$ kuşağındaki hastaların bireysel özellikler ve klinik özellikleri ile antihipertansif ilaç tedavisine uyum ölçeği puan ortalamaları karşılaştırıldığında çalışma durumu, sosyal güvence ve gelir durumu açısından iki grup arasında anlamlı bir farklılık olduğu bulunmuştur $(p<0.05)$. Bunun yanı sıra diğer bireysel ve klinik özelliklerden cinsiyet, medeni durum, eğitim durumu, sigara kullanma, egzersiz yapma ek bir kronik hastalığa sahip olma durumu arasında iki grup arasında anlamlı bir farklılık olmadığı bulunmuştur ( $p>0.05)$.

Araştırmada, X kuşağı hastalarının tedaviye uyumlarının daha iyi olduğu bunun nedeni olarakta bu jenerasyondaki hastaların Bebek Patlaması kuşağına göre daha genç olması hem de $X$ kuşağının karakteristik özelliklerinden daha uyumlu olmalarından kaynaklanabilir. Bu nedenle hemşirelerin ve sağlık ekibinin diğer üyelerinin kuşaklar arası farklılıkları bilmesi ve bu özeliklere göre yönlendirme yapması ve davranış değişiklikleri önermesi önemlidir. Bu sayede kan basıncı kontrolünün sağlanması, komplikasyonların önlenmesi ve hastaların antihipertansif ilaç tedavisine uyumu sağlanmış olacaktır.

9. Mengi Z. X, Y ve Z Birbirinden Çok Farklı. http://www.zeynepmengi. com/2012/06/z-kusagi-geliyor/(Erişim tarihi: 12.01.2018).

10. Etlican G. X ve $Y$ Kuşaklarının Online Eğitim Teknolojilerine Karşı Tutumlarının Karşılaştırılması. Bahçeşehir Üniversitesi Sosyal Bilimler Enstitüsü, Yüksek Lisans Tezi, 2015.

11. Karaaslan S. Kuşaklararası Farklılıkları Örgütler Üzerinden Anlamak: Bir Alan Araştırması. Ankara Üniversitesi Sosyal Bilimler Enstitüsü, Yüksek Lisans Tezi, 2014.

12. Gürbüz S. Kuşak Farklılıkları: Mit mi, Gerçek mi? İş ve İnsan Dergisi 2015; 2: 39-57

13. Gün Y, Korkmaz M. Hipertansif Hastaların Tedavi Uyumu ve Yaşam Kalitesi. Dokuz Eylül Üniversitesi Hemşirelik Yüksekokulu Elektronik Dergisi 2014;7: 98-108.

14. Tümer A, Baybuğa MA, Dereli F, Uysal D. Hipertansiyon Hastalarının Illaç Tedavisine Uyum Düzeyleri. Journal of Cardiovascular Nursing 2016;7:105-13.

15. Atan G, Karabulutlu EY. Esansiyel Hipertansiyonu Olan Hastaların Yaşam Bicimi, Yaşam Kalitesi Ve Tedaviye Uyumunun İncelenmesi. Turkiye Klinikleri 2016; 8:17-25.

16. Mert H, Ozcakar N, Kuruoğlu E. Multidisipliner Bir Özel Çalışma Modülü Araştırması: Hipertansiyon Hastalarının Tedaviye Uyumlarının İncelenmesi. Türk Aile Hek Derg 2011;15:7-12.

17. Aşılar R, Gözüm S. Hipertansif Bireylerin Tamamlayıcı Sağlık Yaklaşımı Kullanımları ve Bunun Antihipertansif İlaç Tedavi Uyumuna Etkisi. TJFMPC 2017; 11: 235-44. 